\title{
Artikkeli
}

Prologi - puheviestinnän vuosikirja 2019

8-20

https://doi.org/10.33352/prlg.80452

\section{Kriisivuorovaikutuksen jännitteet organisaation mainekriiseissä}

\author{
Anni Hammarén \\ FM \\ Content Executive, JD Sports Fashion plc \\ anni.hammaren@hotmail.com
}

\author{
Anne Laajalahti \\ FT \\ koulutus- ja kehittämisjohtaja, Infor ja \\ viestintätieteiden dosentti, Vaasan yliopisto \\ anne.laajalahti@infor.fi
}

\section{Tiivistelmä}

Organisaation mainetta ja mainekriisejä on tutkittu runsaasti eri tieteenaloilla. Tässä artikkelissa syvennetään ymmärrystä organisaation mainekriiseistä kriisivuorovaikutuksen ja mainekriisien parissa työskentelevien viestinnän ammattilaisten näkökulmasta. Aiheen tarkasteluun sovelletaan relationaalisen dialektiikan viitekehystä (Baxter \& Montgomery, 1996). Tutkimuskysymys on seuraava: millaisia kriisivuorovaikutuksen jännitteitä viestinnän ammattilaiset kohtaavat organisaation mainekriisien yhteydessä? Tutkimusaihetta lähestytään mainekriisien parissa työskentelevien viestinnän ammattilaisten kokemana ja kuvaamana. Tutkimus on laadullinen, ja tutkimusaineisto koostuu kahdeksan viestinnän ammattilaisen teemahaastattelusta. Aineisto analysoitiin teoriaohjaavan sisällönanalyysin keinoin. Tulosten mukaan kriisivuorovaikutusta luonnehtii organisaation mainekriiseissä kaksi pääjänniteparia: (1) nopeuden ja harkinnan sekä (2) avoimuuden ja salailun jännite. Nämä jänniteparit jakaantuvat edelleen siten, että nopeuden ja harkinnan jännite sisältää yllätyksellisyyden ja ennakoitavuuden sekä uuden ja perinteisen kriisiviestinnän alajännitteen ja avoimuuden ja salailun jännite sisältää vuorovaikutteisuuden ja yksisuuntaisuuden sekä yhdenmukaisuuden ja moniäänisyyden alajännitteen. Kriisivuorovaikutuksen jännitteiden ymmärtäminen auttaa mainekriisien hallinnassa, kriisivuorovaikutuksen kehittämisessä sekä viestinnän ammattilaisten tukemisessa työssään. Päätännössä tuodaan esille tutkimustulosten sovelluskohteita ja jatkotutkimustarpeita. Lisäksi arvioidaan relationaalisen dialektiikan soveltuvuutta viestinnän ammattilaisten työn tarkasteluun mainekriisien yhteydessä.

ASIASANAT: kriisiviestintä, kriisivuorovaikutus, mainekriisi, relationaalinen dialektiikka, vuorovaikutuksen jännitteet

${ }^{1}$ Artikkeli perustuu FM Anni Hammarénin (2018) puheviestinnän pro gradu -tutkielmaan, jonka ohjaajana toimi koulutus- ja kehittämisjohtaja, FT Anne Laajalahti Inforista. 


\section{Johdanto}

"It takes 20 years to build a reputation and five minutes to ruin it. If you think about that, you'll do things differently." - Warren Buffett

Organisaation maine on sidosryhmien tekemä arvio organisaatiosta perustuen esimerkiksi sen taloudellisiin, sosiaalisiin ja ympäristövaikutuksiin. Maineeseen vaikuttavat niin ihmisten omat kokemukset kuin vaikkapa tuttujen kesken tai perinteisessä ja sosiaalisessa mediassa rakennetut ja jaetut mainetarinat. (Laaksonen, 2017; Sohn \& Lariscy, 2014.) Maine on organisaatiolle tärkeää strategista pääomaa: se vaikuttaa luottamukseen, kilpailukykyyn sekä suhteisiin nykyisten ja potentiaalisten työntekijöiden, asiakkaiden, yhteistyökumppaneiden, sijoittajien ja muiden sidosryhmien kanssa (Benoit, 2015; Carroll, 2016). Siksi mainekriisi tai sen uhka on aina vakava paikka organisaatiolle.

Erilaiset somekohut ja mainekriisit ovat nykyisin arkipäivää esimerkiksi politiikassa, urheilussa ja viihdemaailmassa, mutta myös kaikki organisaatiot voivat joutua mainekriisiin. Syynä voi olla, että organisaatio tekee sidosryhmien mielestä jotain väärin - tai jättää tekemättä jotain oikein. Digitaalisen julkisuuden uusi logiikka ja etenkin sosiaalinen media ovat muuttaneet mainekriisien luonnetta (McCorkindale \& Distaso, 2013; Ott \& Theunissen, 2015). Periaatteessa kuka tahansa voi esittää sosiaalisessa mediassa mielipiteitään, ja erilaiset organisaation mainetta uhkaavat hyökkäykset ja kritiikki voivat levitä nopeasti ja laajalle. Tämä on tehnyt mainekriisien hallinnasta entistä haastavampaa ja muuttanut myös kriisiviestinnän vaatimuksia (Goodman, 2017; Ott \& Theunissen, 2015). On yhä vaikeampaa ennustaa, milloin mainekriisi syntyy, miten se etenee ja mitä siitä seuraa.
Organisaation maine ja mainekriisit ovat yleisiä tutkimuskohteita (Carroll, 2016). Organisaatioiden kriisiviestintää on tarkasteltu perinteisesti yksisuuntaisena, ylhäältä alaspäin ja sisältä ulospäin suuntautuvana toimintana (Falkheimer \& Heide, 2012). Tässä artikkelissa syvennetään ymmärrystä organisaation mainekriiseistä vuorovaikutuksen näkökulmasta ja tarkastellaan, millaisessa vuorovaikutusympäristössä viestinnän ammattilaiset työskentelevät organisaation mainekriiseissä. Näkökulman muutosta korostetaan käyttämällä kriisiviestinnän sijaan kriisivuorovaikutuksen käsitettä (Laajalahti, 2016; Laajalahti, Hyvärinen, \& Vos, 2016). Kriisivuorovaikutuksen tarkasteluun sovelletaan relationaalisen dialektiikan viitekehystä (Baxter \& Montgomery, 1996).

\section{Organisaatioiden mainekriisit}

Kriisi on uhkaava tilanne tai tapahtumien sarja, jota luonnehtivat ennakoimattomuus, yllätyksellisyys, epävarmuuden lisääntyminen ja lyhyt reagointiaika (Ulmer, Sellnow, \& Seeger, 2015). Usein kriisin määritelmään lisätään negatiiviset seuraukset (Coombs, 2007), mutta kriisi voi auttaa organisaatiota myös oppimaan ja kehittymään paremmaksi (Ulmer ym., 2015). Kriisille ei aina voida nimetä tarkkaa alku- tai päätepistettä, vaan sitä on usein mielekkäämpää tarkastella prosessina (Reynolds \& Seeger, 2005).

Kun organisaatio ajautuu kriisiin, usein myös sen maine on vaakalaudalla. Coombsin (2007) mukaan kriisi aiheuttaa uhan organisaation normaalille toimintakyvylle, taloudelle ja maineelle. Organisaation maine koostuu mielipiteistä ja havainnoista, joita sidosryhmät muodostavat organisaation ominaispiirteitä, suoriutumista ja toimintaa arvioimalla (Sohn \& Lariscy, 2014). Organisaation maine on samaan aikaan olemassa sekä yksilöllisinä tulkintake- 
hyksinä että sosiaalisesti rakennettuina ja jaettuina mainetarinoina (Laaksonen, 2017).

Mainekriisi on julkisuuteen nouseva negatiivinen tapahtuma tai tapahtumasarja, joka saa keskeiset sidosryhmät arvioimaan uudelleen vaikutelmiaan organisaatiosta (Sohn \& Lariscy, 2014). Sidosryhmien tekemät uudelleenarvioinnit eivät kuitenkaan aina ole negatiivisia, vaan onnistuneella kriisiviestinnällä voidaan jopa parantaa sidosryhmien muodostamaa kuvaa organisaatiosta (Coombs, 2013; Ulmer ym., 2015). Mainekriisi uhkaa siis organisaation mainetta, muttei välttämättä aiheuta vahinkoa. Sidosryhmien tekemät tulkinnat määrittävät lopulta, onko organisaatio mainekriisissä vai ei (Coombs, 2007).

\section{Kriisiviestintää vai kriisivuorovaikutusta?}

Mainekriisejä pyritään johtamaan ja hallitsemaan viestinnän avulla. Kriisiviestintä on jatkuva prosessi, jonka avulla organisaatio tarkkailee ympäristöään ennen kriisiä, sen aikana ja jälkeen. Kriisiviestintä auttaa organisaatiota hahmottamaan tilannetta, ymmärtämään sidosryhmiä ja vastaamaan näille tarkoituksenmukaisella tavalla. (Ulmer ym., 2015.) Kriisiviestintä edellyttää tiedon keräämistä, prosessointia ja jakamista (Coombs, 2007). Mainekriiseissä kriisiviestinnällä pyritään lisäksi estämään ja korjaamaan organisaation mainevahinkoja. Tällöin keskeisessä asemassa ovat strategiset valinnat, miten organisaatio päättää vastata mainekriisiin tai sen uhkaan ja pyrkiä korjaamaan syntyneitä vahinkoja ( $c r i-$ sis response strategies; image repair strategies). Toisin kuin vaikkapa luonnonkatastrofien yhteydessä, mainekriiseissä viestinnällä voidaan toisinaan jopa poistaa koko kriisi tai ainakin minimoida sen negatiiviset vaikutukset. (Benoit, 2015; Coombs, 2013.)
Digitaalisen julkisuuden uusi logiikka ja erityisesti sosiaalinen media ovat vaikuttaneet kriisiviestintään ja mainekriisien hallintaan (Cheng, 2016; Goodman, 2017; McCorkindale \& Distaso, 2013; Ott \& Theunissen, 2015). Nykyisin erilaisilla sidosryhmillä on mahdollisuus tuoda mielipiteensä kuuluviin sosiaalisen median julkisilla areenoilla ja levittää näkemyksiään nopeasti laajoille yleisöille. Organisaatioille tämä on merkinnyt lisääntynyttä mainekriisien ja kritisoinnin kohteeksi joutumisen mahdollisuutta. Sosiaalisen median keskustelut ja sisällöt eivät ole samalla tavalla organisaatioiden hallittavissa kuin perinteisen median sisällöt. (Ott \& Theunissen, 2015.) Esimerkiksi organisaation toimintaan tyytymättömät sidosryhmät voivat tuoda kritiikkinsä julki sosiaalisessa mediassa ja vaikuttaa näin muidenkin mielipiteisiin. Toisaalta organisaatiot voivat tukahduttaa kyteviä kriisejä ja oikaista väärinkäsityksiä käymällä keskustelua sosiaalisessa mediassa.

Aiemmin sidosryhmät on nähty lähinnä kriisiviestien passiivisina vastaanottajina, ja tarkastelu on keskittynyt siihen, miten ja millaisten viestien avulla organisaatiot voivat vaikuttaa sidosryhmien käyttäytymiseen ja mielipiteisiin (Avery, Lariscy, Kim, \& Hocke, 2010). Sosiaalinen media on kuitenkin mahdollistanut vuorovaikutteisemman kriisiviestinnän, ja erilaiset sidosryhmät ovat ottaneet aktiivisemman roolin kriisiviestinnässä (Cheng, 2016; Kietzmann, Hermkens, McCarthy, \& Silvestre, 2011).

Organisaatioiden kriisiviestintää on tarkasteltu perinteisesti yksisuuntaisena, ylhäältä alaspäin ja sisältä ulospäin suuntautuvana toimintana (Falkheimer \& Heide, 2012). Kriisiviestintä ei ole kuitenkaan vain yksisuuntaista kriiseistä tiedottamista ja uutisointia tai organisaation kriisiviestintästrategioiden ja -suunnitelmien laatimista: kriisit edellyttävät monipuolista vuorovaikutusta eri toimijoiden kesken niin 
organisaatioiden sisällä ja välillä kuin eri sidosryhmien kanssa. Onkin ehdotettu, että kriisiviestinnän tutkimuksissa tulisi kiinnittää enemmän huomiota kaikkeen siihen ihmisten väliseen vuorovaikutukseen, jota tarvitaan kriiseihin varautumisessa ja ennalta ehkäisemisessä, kriisien hallinnassa ja niihin vastaamisessa sekä kriiseistä toipumisessa ja oppimisessa. Lisäksi on ehdotettu, että tätä näkökulman muutosta voitaisiin korostaa käyttämällä kriisiviestinnän sijaan käsitettä kriisivuorovaikutus. (Laajalahti, 2016; Laajalahti ym., 2016.) Tässä artikkelissa ollaan kiinnostuneita erityisesti tämänkaltaisesta kriisivuorovaikutuksesta, johon viestinnän ammattilaiset osallistuvat organisaation mainekriiseissä. Koska mainekriisejä tarkastellaan nimenomaan vuorovaikutuksen näkökulmasta, artikkelissa käytetään kriisivuorovaikutuksen käsitettä korostamaan näkökulman vaihdosta.

\section{Vuorovaikutuksen jännitteet kriisiviestinnässä}

Relationaalinen dialektiikka on laaja teoreettinen viitekehys, joka kokoaa yhteen vuorovaikutussuhteiden jännitteitä tarkastelevia tutkimuksia (Baxter \& Braithwaite, 2010; Gerlander \& Kostiainen, 2005). Jännitteet voivat olla joko vuorovaikutussuhteen sisäisiä tai ulkoisia vastakkaisia voimia, ja ne tekevät suhteista dynaamisia, jatkuvasti kehittyviä ja muuttuvia (Baxter \& Montgomery, 1996). Jännitteet eivät ole lähtökohtaisesti "hyviä" tai "pahoja". Ne eivät siis ole "ongelmia", jotka voisi tai pitäisi korjata, vaan luonnollinen, perustavanlaatuinen osa vuorovaikutussuhteiden dynamiikkaa. (Baxter \& Norwood, 2015.)

Relationaalisen dialektiikan viitekehys on muuttunut vuosien mittaan (Cools, 2011), ja sen uusimmissa versioissa on tarkennettu, että jännitteillä tarkoitetaan ristiriitojen sijaan pi- kemminkin erilaisten kilpailevien diskurssien kamppailua (Baxter \& Braithwaite, 2010; Baxter \& Norwood, 2015). Myös relationaalisen dialektiikan sovelluskohteet ovat laajentuneet: viitekehys luotiin perhe-, pari- ja ystävyyssuhteiden tarkasteluun (Baxter \& Montgomery, 1996), mutta sittemmin sitä on sovellettu myös työelämän vuorovaikutussuhteiden tutkimiseen (ks. esim. Gerlander, 2003; Gerlander \& Kostiainen, 2005).

Relationaalisen dialektiikan näkökulmasta on tarkasteltu usein jotain tiettyä vuorovaikutussuhdetta, mutta työelämässä, organisaatioissa ja vuorovaikutuksessa esiintyviä jännitteitä, ristiriitaisuuksia ja paradokseja on tutkittu yleisemminkin keskittymättä mihinkään tiettyyn vuorovaikutussuhteeseen (Putnam, Fairhurst, \& Banghart, 2016). Tällöin tarkastelun kohteena ovat olleet vuorovaikutuksen jännitteet laajemminkin esimerkiksi toimittajien (Gerlander, Hautakangas, \& Ahva, 2018) ja tutkijoiden työssä (Laajalahti, 2014). Vuorovaikutuksen jännitteitä on tarkasteltu jonkin verran myös kriisiviestinnän yhteydessä (ks. esim. Carlson, Poole, Lambert, \& Lammers, 2017; Littlefield \& Sellnow, 2015). Kriisiviestinnän tutkimuksissa on selvitetty usein erilaisia tapoja vastata kriiseihin eli sitä, millaisia päätöksiä kriiseissä tehdään, ja relationaalisen dialektiikan näkökulmalla on syvennetty ymmärrystä siitä vuorovaikutusympäristöstä, jossa päätöksiä tehdään (Littlefield, 2015).

Kriisien epävakaus ja kaoottisuus lisäävät tarvetta ymmärtää niiden jännitteistä luonnetta (Carlson ym., 2017; Littlefield, 2015). Tässä tutkimuksessa tarkastellaan organisaation mainekriisejä viestinnän ammattilaisten kohtaamien vuorovaikutuksen jännitteiden näkökulmasta. Tämä on tärkeää, koska viestinnän ammattilaiset työskentelevät aktiivisesti organisaation maineen- ja kriisinhallinnan pa- 
rissa (Beurer-Züllig, Fieseler, \& Meckel, 2009; Viestinnän ammattilaiset, 2017) ja koska viestinnällä on tärkeä rooli jännitteiden määrittelyssä, ongelmanratkaisussa, päätöksenteossa ja jännitteisiin vastaamisen implementoinnissa (Carlson ym., 2017). Tutkimuskysymys on seuraava: millaisia kriisivuorovaikutuksen jännitteitä viestinnän ammattilaiset kohtaavat organisaation mainekriisien yhteydessä?

\section{Menetelmät}

Kriisivuorovaikutuksen jännitteitä lähestytään organisaation mainekriisien parissa työskentelevien viestinnän ammattilaisten kokemana ja kuvaamana. Tutkimus on laadullinen, ja tutkimusaineisto koostuu kahdeksan viestinnän ammattilaisen teemahaastattelusta (Hirsjärvi \& Hurme, 2008), jotka tehtiin toukokuussa 2018. Viisi haastateltavaa työskenteli viestintäpäällikkönä ja kolme viestintäjohtajana, seitsemän yrityksessä ja yksi kansalaisjärjestössä. Kriteerinä tutkimukseen osallistumiselle oli, että haastateltava työskenteli viestinnän johtotehtävissä ja että hänen työhönsä kuuluivat kriisiviestinnän tehtävät.

Haastattelupyyntö jaettiin neljässä Facebook-yhteisöpalvelun viestintäjohtajille ja -päälliköille suunnatussa ryhmässä ja lähetettiin sähköpostilla 50 viestinnän ammattilaiselle, joiden yhteystiedot saatiin verkkosivuilta tai lähipiirin kautta. Haastateltavaksi valikoituivat kaikki ne haastattelupyynnön saaneet henkilöt, jotka kokivat täyttävänsä yllä kuvatut kriteerit ja halusivat jakaa kokemuksiaan. Haastateltavilla oli 5-29 vuoden kokemus viestinnän tehtävistä; keskimäärin he olivat työskennelleet 16 vuotta alalla. Kaikilla heillä oli kokemusta vastuullisista viestintätehtävistä mainekriiseissä yhdestä tai useammasta organisaatiosta.
Kaikki haastattelut tehtiin maantieteellisten etäisyyksien vuoksi Skype- tai WhatsApp-verkkopuhelimella, ja puhelut nauhoitettiin analyysiä varten. Haastattelut kestivät keskimäärin 47 minuuttia; lyhin oli 27 ja pisin 64 minuuttia. Haastatteluteemojen käsittelyjärjestys vaihteli, ja haastattelut pidettiin avoimina keskustelun edetessä esiin nouseville aiheille, mutta kaikkien kanssa käytiin läpi seuraavat teemat: organisaatiolle mahdolliset ja tyypilliset mainekriisit, mainekriisien hallinta ja kriisiviestintä, kriisiviestinnän vuorovaikutteisuus, vuorovaikutus sidosryhmien kanssa mainekriiseissä, vuorovaikutusosaaminen mainekriiseissä sekä kokemuksellisesti merkittävät vuorovaikutustilanteet mainekriiseissä.

Kuten laadullisille tutkimuksille on ominaista (Tuomi \& Sarajärvi, 2018), myös tässä tutkimuksessa tutkimustehtävä tarkentui tutkimusprosessin edetessä: kriisivuorovaikutuksen jännitteet hahmottuivat tutkimuskysymykseksi vasta aineiston analyysivaiheessa. Haastateltavilta ei siis suoraan kysytty mitään vuorovaikutuksen jännitteistä, vaan relationaalisen dialektiikan näkökulma otettiin käyttöön aineistoa analysoitaessa. Haastattelut litteroitiin sanatarkasti, ja litteroitua aineistoa kertyi yhteensä 78 sivua (38 486 sanaa). Haastateltaville annettiin koodinimet haastattelun järjestysnumeron ja sen perusteella, työskentelikö haastateltava viestintäjohtajana (VJ) vai viestintäpäällikkönä (VP). Haastateltavien toiveesta heidän toimialojaan ei raportoida, ettei heitä tai heidän työskentelyorganisaatiotaan voida tunnistaa.

Aineiston keräsi ja analysoi ensimmäinen kirjoittaja yksin, mutta tuloksista ja niiden tulkinnasta neuvoteltiin yhdessä. Aineisto analysoitiin teoriaohjaavan sisällönanalyysin keinoin. Teoriaohjaavassa analyysissä aiempaa tutkimustietoa käytetään analyysin apuna, mutta analyysiyksiköt muodostetaan aineistosta 
(Tuomi \& Sarajärvi, 2018). Tässä tutkimuksessa teoriaohjaavuus tarkoitti sitä, että analyysissä hyödynnettiin Baxterin ja Montgomeryn (1996) relationaalisen dialektiikan viitekehystä kriisivuorovaikutuksen jännitteisen luonteen hahmottamisessa. Tutkimustulokseksi saadut jänniteparit muodostuivat kuitenkin aineistolähtöisesti, ja jännitteiden molemmat ääripäät löytyivät suoraan haastateltavien puheesta. Haastateltavat kuvasivat kriisivuorovaikutusta lähtökohtaisesti jännitteisenä, ja haastatteluista löytyi runsaasti jännitteisyyden pohdintaa. Tämä toistui haastateltavien puheessa esimerkiksi "toisaalta ja toisaalta", "mutta myös", "mutta kuitenkin" -kaltaisina ilmauksina.

Analyysin aluksi litteroitu aineisto luettiin useaan kertaan huolella läpi. Aineistosta etsittiin tutkimuskysymyksen kannalta oleellisia merkityksenantoja, jotka kuvastivat niitä kriisivuorovaikutuksen jännitteitä, joita viestinnän ammattilaiset kohtaavat mainekriiseissä. Jännitteisiin liittyvät aineistokohdat merkittiin litteroituun aineistoon. Sen jälkeen aineistokohdat siirrettiin erillisiin tiedostoihin, yksittäisten lausumien abstraktiotasoa nostettiin ja kukin jännitepari nimettiin (esim. nopeuden ja harkinnan jännite). Aineiston pilkkominen omiin tiedostoihin helpotti tulkintaa ja jänniteparien välisten suhteiden hahmottamista. Tämän seurauksena jänniteparit jaoteltiin kahteen pääännitteeseen ja niiden alle asettuviin alajännitteisiin.

\section{Tulokset}

\section{Kriisivuorovaikutuksen jännitteet mainekriiseissä}

Tutkimukseen osallistuneiden viestinnän ammattilaisten mukaan kriisiviestintä on mainekriiseissä hyvin vuorovaikutteista toimintaa: esimerkiksi kriisien ennakoiminen, kriisiym- märryksen muodostaminen ja kriiseihin vastaamistavoista neuvotteleminen vaativat vuorovaikutusta eri sidosryhmien kanssa. Pelkkä yksisuuntainen viestintä ei siis riitä, vaan mainekriisien onnistunut hallinta vaatii viestinnän ammattilaisilta aktiivista vuorovaikutusta niin organisaation sisäisten kuin ulkoisten sidosryhmien kanssa.

Tulosten mukaan mainekriisien hallinnassa ja kriisivuorovaikutuksessa esiintyvät jänniteparit jakaantuvat kahteen pääjännitteeseen ja näiden alle asettuviin alajännitteisiin:

(1) nopeuden ja harkinnan jännite

- yllätyksellisyyden ja ennakoitavuuden jännite

- $\quad$ uuden ja perinteisen kriisiviestinnän jännite

(2) avoimuuden ja salailun jännite

- vuorovaikutteisuuden ja yksisuuntaisuuden jännite

- yhdenmukaisuuden ja moniäänisyyden jännite.

(1) Nopeuden ja harkinnan jännite. Tutkimusta varten haastatellut viestinnän ammattilaiset korostivat nopean toiminnan ja päätöksenteon tärkeyttä mainekriiseissä. Mainekriisi tai sen uhka on tunnistettava ja tilanteeseen on reagoitava mahdollisimman pian, koska sillon se organisaatio saa siinä tavallaan yliotteen (VP2). Viestinnän ammattilaisen on selvitettävä nopeasti, miten mainekriisi on saanut alkunsa, keitä se koskettaa ja millaisia seurauksia sillä voi olla. Kriisiin liittyvien tietojen kerääminen ja tapahtumien selvittely tapahtuvat ennen kaikkea vuorovaikutuksessa. 
Nopea keskustelun aloittaminen ei kuitenkaan aina ole yksinkertaista, sillä kriisivuorovaikutuksen tulee olla samaan aikaan tarkkaan harkittua: väärän tiedon antaminen esimerkiksi medialle voi pahentaa kriisiä ja syyllisyyden myöntämisellä (VP3) voi olla vakavia seurauksia. Nopeuden ja harkinnan välinen jännite näkyy myös organisaation sisäisessä vuorovaikutuksessa. Mainekriisit ja niiden uhat on toisaalta nostettava nopeasti keskusteluun, mutta toisaalta osa haastateltavista koki kriisin käsitteen itsessään jännitteisenä ja näki, että kriisin nimeäminen kriisiksi saattaa lisätä kiireen, stressin ja jopa hädän tuntua. Tämän vuoksi heidän täytyy olla erityisen varovaisia, että $e i$ puhuta jostain kohusta tai kriisistä [---] tai et ei niinku vettä myllyyn vaan semmonen rauhallisuus (VP3).

\section{Yllätyksellisyyden ja ennakoitavuuden jänni-}

te. Mainekriisit ovat lähtökohtaisesti yllätyksellisiä: kriisien syntymistä ja kehitystä on vaikea ennakoida. Esimerkiksi sosiaalisessa mediassa on vaikeaa ennustaa, millainen vuorovaikutus voi synnyttää kriisin: se on hallitsematonta se keskustelu (VP8) ja $y k s$ ainut tokasu trendaa Twitterissä hyvin nopeesti, ja niitä tokasuja voi tulla paineen alla helposti (VP7). Viestinnän ammattilainen ei siis voi tarkkaan harkita tai suunnitella vuorovaikutusta etukäteen, vaan improvisointiin ja hetkessä tehtyihin päätöksiin nojaava ripeä toiminta korostuu.

Samaan aikaan kun on pystyttävä reagoimaan yllätyksellisiin ja ennakoimattomasti eteneviin mainekriiseihin, viestinnän ammattilaisilta edellytetään suunnitelmallisuutta ja ennakoitavuutta. Esimerkiksi sosiaalisessa mediassa vuorovaikutuksen on usein noudatettava tiettyä toistuvaa kaavaa. Viestinnän ammattilaiset kokivat, että vain erilaisia sääntöjä (VJ6) ja maneereja noudattamalla organisaatio pääsee pinteestä (VJ6). Toisaalta haastateltavat koros- tivat, ettei organisaatio saisi piiloutua valmiiksi pohdittujen lausuntojen taakse, vaan vuorovaikutuksen tulisi olla aidosti kuuntelevaa (VP1) ja läsnä olevaa (VJ5).

\section{Uuden ja perinteisen kriisiviestinnän jännite.}

Viestinnän ammattilaiset kertoivat hyödyntävänsä erilaisia viestintäteknologioita ja -sovelluksia kriisivuorovaikutuksessa. Tarvittaessa uutta teknologiaa käytetään jopa organisaation omaa viestintäetikettiä rikkoen: kriisin taltuttamiseksi voidaan ottaa kaikki mahdolliset keinot ja kanavat käyttöön (VP3). Esimerkiksi lähinnä brändin ja positiivisen mielikuvan rakentamiseen käytetty Instagram-sovellus saatetaan valjastaa mainekriiseissä kriisivuorovaikutuksen välineeksi sidosryhmien kanssa. Viestinnän ammattilaiset kertoivat hyödyntävänsä erilaisia pikaviestimiä myös organisaation sisäisessä kriisivuorovaikutuksessa, vaikka näiden käyttö olisikin kielletty tietoturvallisuusriskin vuoksi. Yleisesti käytettyjen, tuttujen pikaviestimien koettiin olevan kaikista nopeimpia ja helpoimpia, et tavottaa kaikki (VJ5) ja soveltuvan usein kriisivuorovaikutustarpeisiin paremmin kuin johdon määräämien mutta harvakseltaan käytettyjen viestintäteknologioiden.

Vaikka uusien viestintäteknologioiden roolia korostettiin, viestinnän ammattilaisten mukaan organisaatiot tarvitsevat yhä perinteisen median apua mainekriisien hallinnassa. Toimittajien kanssa muodostettujen vuorovaikutussuhteiden koettiin kuitenkin kiristyneen uutissyklin nopeutuessa ja sisältöjen viihteellistyessä. Viestinnän ammattilaiset kokivat, että heidän on tasapainoiltava sen välillä, vaatiiko kriisinhallinta uusien teknologioiden hyödyntämistä, jolloin tavoitetaan nopeasti eri sidosryhmät, vai vastaako perinteinen kriisiviestintä paremmin kriisivuorovaikutuksen tarpeisiin, jolloin annettujen lausuntojen tulee olla erityisen tarkkaan harkittuja. 
(2) Avoimuuden ja salailun jännite. Viestinnän ammattilaisten mukaan avoin vuorovaikutus on mainekriiseissä tärkeää niin sisäisten kuin ulkoisten sidosryhmien kanssa: reilusti kerrotaan se, mitä on tapahtunu ja miks on tapahtunu (VP2). Koska ihmisillä on luontainen taipumus olla kertomatta ihan kaikkee, mitä tuli töpättyä (VP3), vahvistamalla organisaation avointa vuorovaikutuskulttuuria voidaan edistää, ettei tehtyjä virheitä jätetä kertomatta esimerkiksi oman aseman suojelemisen, kasvojen säilyttämisen tai rangaistuksen pelon vuoksi. Avoimuus on tärkeää, koska ajoissa saatujen varoitussignaalien avulla kriisi voidaan jopa estää kokonaan. Haastateltavat kertoivat, että myös organisaation ulkoisille sidosryhmille tulisi kertoa avoimesti, mitä on tapahtunut ja miksi. Organisaation on kyettävä avoimeen keskusteluun myös sillon ku palaute on kriittistä (VP3). Avoimella vuorovaikutuksella ja omien virheiden myöntämisellä pyritään ylläpitämään organisaation ja sidosryhmien välistä luottamusta.

Toisaalta viestinnän ammattilaiset korostivat, että heidän on pohdittava, kuinka suuri avoimuus on organisaation edun mukaista. Esimerkiksi toimittajien kanssa vuorovaikutuksen tulee olla avointa, muttei hullun avointa (VJ5), eikä kriisiä pidä itse mehevöittää liikaa totuuksilla (VJ5). Avoimella vuorovaikutuksella pyritään estämään väärien tietojen leviäminen, mutta mainevahinkojen minimointi on pidettävä etusijalla. Toimittajille saatetaan paljastaa esimerkiksi vain osa totuudesta tai kriisin seurauksia saatetaan vähätellä. Viestinnän ammattilaisten onkin pyrittävä avoimuuteen mutta toisaalta harkittava tarkkaan, mitä he voivat paljastaa ja kenelle.

Vuorovaikutteisuuden ja yksisuuntaisuuden jännite. Vastavuoroinen kanssakäyminen on tärkeää avoimen vuorovaikutuskulttuurin luomisessa, eikä pelkkä yksisuuntainen viestintä riitä ulkoisten sidosryhmienkään kanssa, joskus saattaa olla, että tarvitaan jotain face-to-face-tapaamista, mikä on tietysti kaikkein tehokkain ja paras, jos sellaseen pystyy (VJ4). Esimerkiksi toimittajien kanssa viestinnän ammattilaisten tulisi pystyä joustavaan vuorovaikutukseen, vaikka organisaatio olisikin suunnitellut medialle annettavat lausunnot etukäteen. Viestinnän ammattilainen ei saisi muuttua koneeks, joka vaan puhuu sitä mitä on käsketty puhumaan (VP7).

Toisaalta viestinnän ammattilaiset kertoivat rajoittavansa vuorovaikutustaan yksisuuntaisemmaksi etenkin silloin, kun tietoa ei ole tai organisaatio ei halua paljastaa kaikkea. Viestinnän ammattilaiset kokivat vastavuoroisen ja nonverbaalisia vihjeitä sisältävän vuorovaikutuksen olevan toisinaan liian paljastavaa mutta toivat myös esille, ettei yksisuuntainen ja vähemmän vuorovaikutteinen viestintä ole ongelmatonta sekään. Nonverbaalisten vihjeiden rajallisuus saattaa lisätä väärinkäsitysten mahdollisuutta, ku se viestintä ei oo niin rikasta (VP1). Etenkin median koettiin hyödyntävän sähköpostilla tai muilla tiedotteilla annettuja lausuntoja irrottamalla asioita kontekstista ja vääristämällä sisältöä viihteellisemmäksi. Tasapainoillessaan vuorovaikutteisuuden ja yksisuuntaisuuden välillä viestinnän ammattilaisten on harkittava tarkkaan, kumpi tapa soveltuu paremmin kyseisen mainekriisin selvittämiseen.

\section{Yhdenmukaisuuden ja moniäänisyyden jän-} nite. Sopivan avoimen ja vuorovaikutteisen viestinnän lisäksi viestinnän ammattilaiset korostivat yhdenmukaisuutta mainekriiseissä. Organisaation tulisi puhua asioista yhdellä ä̈̈nellä (VP1), yhdessä sovituin ja yhteneväisin lausunnoin. Esimerkiksi sosiaalisessa mediassa yhteisen linjan rikkominen saattaa pahentaa mainekriisiä, ja siksi $y k s$ ihminen antaa lausuntoja, [---] ja muut ei mee sitte niinku sooloile- 
maan (VJ4). Yhdenmukaisuudella pyritään siis minimoimaan mainevahingot.

Tiukka yhdenmukaisuus ei kuitenkaan yksinään riitä: haastateltavat kokivat, että vain virallisiin lausuntoihin nojautuminen saattaa uhata organisaation uskottavuutta ja organisaatio saatetaan nähdä epäaitona ja etäisenä. Moniääninen vuorovaikutus on tärkeää etenkin sosiaalisessa mediassa: omien työntekijöiden lisäksi sidosryhmien muodostamat tukijoukot (VP8) ovat tärkeitä organisaation maineen puolustajia. Organisaatioiden mainekriisien hallinta muodostuu siis monipuolisesta kriisivuorovaikutuksesta, jonka on oltava samaan aikaan sekä riittävän yhdenmukaista että moniäänistä.

Kriisivuorovaikutuksen jännitteiden yhdistelmät mainekriiseissä

Kriisivuorovaikutuksen jännitteiden tarkastelusta tekee kiinnostavaa, etteivät ne esiinny yksinään tai tyhjiössä: viestinnän ammattilai- set työskentelevät mainekriiseissä vuorovaikutusympäristössä, jossa on samaan aikaan läsnä erilaisia kriisivuorovaikutuksen jännitteitä. Viestinnän ammattilaiset joutuvat siis samaan aikaan tasapainoilemaan useamman jännitteen välillä ja ottamaan kantaa, miten he jännitteisiin vastaavat ja mitä he toiminnassaan priorisoivat. Alla olevaan kuvioon 1 on koottu tämän tutkimuksen pääjänniteparien, nopeuden ja harkinnan sekä avoimuuden ja salailun, muodostamat yhdistelmät.

Kriisivuorovaikutuksen jännitteet heijastuvat myös niihin vuorovaikutusstrategioihin ja tiedostettuihin tai tiedostamattomiin valintoihin, joita viestinnän ammattilaiset ja kokonaiset organisaatiot tekevät organisaation mainekriisien yhteydessä. Kriisivuorovaikutuksen onnistumisen kannalta ei ole yhdentekevää, onko kriisivuorovaikutus mainekriiseissä esimerkiksi nopeaa ja avointa vai harkitsevaa ja avointa tai esimerkiksi nopeaa ja salailevaa vai harkitsevaa ja salailevaa. Jännitteiden luonteeseen kuuluu

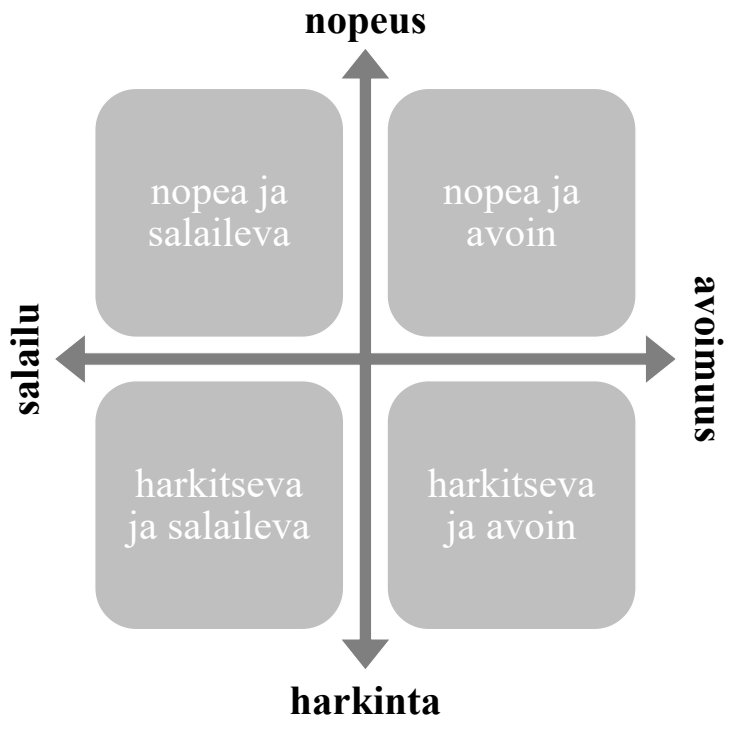

KUVIO 1 Kriisivuorovaikutuksen jännitteiden yhdistelmät 
kuitenkin, ettei niihin ole yhtä oikeaa kaikkiin tilanteisiin soveltuvaa reagointitapaa. Jännitteiden samanaikainen läsnäolo ja keskinäinen vuoropuhelu tekevät kriisivuorovaikutuksesta alati muuttuvaa sekä jatkuvaa uudelleen tulkintaa vaativaa toimintaa.

\section{Päätäntö}

Mainekriisien ominaispiirteet, kuten nopeatempoisuus, yllätyksellisyys ja sidosryhmien eriävät tavoitteet, tekevät niistä kiehtovan vuorovaikutuksen jännitteiden tarkastelukohteen, ja tulosten mukaan jännitteisyys on mainekriisien vuorovaikutukselle tyypillistä. Kriisivuorovaikutuksen jännitteiden ymmärtäminen auttaa mainekriisien hallinnassa, kriisivuorovaikutuksen kehittämisessä ja viestinnän ammattilaisten tukemisessa työssään. Esimerkiksi nopeuden ja harkinnan jännitteen tiedostaminen voi auttaa viestinnän ammattilaisia vastaamaan vuorovaikutuksen ajoittamisen ja ajantasaisuuden vaatimuksiin. Avoimuuden ja salailun jännitteen tiedostaminen voi sen sijaan auttaa heitä ymmärtämään, mitä kannattaa kertoa, kenelle ja milloin.

Littlefieldin (2015) mukaan organisaatiot kohtaavat kriiseissä samantyyppisiä jännitteitä kuin ihmiset vuorovaikutussuhteissaan: keskeistä on muun muassa, miten paljon tietoa jaetaan, miten varmuus ja epävarmuus ilmaistaan ja miten viestintä ajoitetaan. On myös esitetty, että tietty perusdialektiikka yhdistää kaikkia samankaltaisia vuorovaikutussuhteita tietyssä historiallis-kulttuurisessa kontekstissa, vaikka kaikissa suhteissa on myös kullekin suhdetyypille ominaisia ja jopa yksittäisille suhteille spesifejä jännitteitä (Gerlander, 2003).

Tässä tutkimuksessa esille tulleet kriisivuorovaikutuksen jännitteet ovat monin osin samantyyppisiä kuin aiemmissa kriisiviestinnän tutkimuksissa: esimerkiksi viestinnän ajoittamiseen ja ajantasaisuuteen, avoimuuteen, varmuuteen sekä kriisinarratiivien kontrollointiin liittyviä haasteita on nostettu esille aiemminkin (Littlefield \& Sellnow, 2015). Sen sijaan tunteisiin liittyviä jännitteitä haastateltavat eivät juurikaan kuvanneet, vaikka kriisit edellyttävät myös emotionaalisten jännitteiden hallintaa (Littlefield, 2015). Koska kriisiviestinnän tarkastelua ei ole mielekästä rajata vain kognitiivisiin aspekteihin, kuten tiedon tarpeisiin ja vaihdantaan kriiseissä, jatkossa olisi tarpeen tutkia erityisesti kriisivuorovaikutuksen jännitteiden emotionaalisia ulottuvuuksia (ks. lisäksi Laajalahti ym., 2016).

Tehty tutkimus osoittaa, että relationaalisen dialektiikan viitekehystä voidaan soveltaa vuorovaikutuksen jännitteiden tarkasteluun jossain tietyssä työssä keskittymättä mihinkään tiettyyn vuorovaikutussuhteeseen. Jatkossa rajautuminen tiettyyn vuorovaikutussuhteeseen voisi kuitenkin tarjota tärkeää lisätietoa siitä, miten vuorovaikutussuhteet etenevät ja muuttuvat mainekriiseissä. Vuorovaikutuksen jännitteitä on tutkittu usein kahdenkeskisissä vuorovaikutussuhteissa (Baxter \& Braithwaite, 2010), mutta niitä olisi kiinnostavaa tarkastella myös ryhmätasolla sekä tutkimalla yksilöiden sijaan kokonaisten viestintäyksiköiden yhteisiä merkityksenantoja ja toimintaa. Kiinnostavaa olisi myös selvittää tarkemmin, millaisia yhdistelmiä eri kriisivuorovaikutuksen jännitteet muodostavat ja millaisia uusia jännitteitä erilaiset jännitteisiin vastaamistavat mahdollisesti synnyttävät (ks. lisäksi Currie-Mueller, 2017).

Tässä tutkimuksessa haastateltiin kahdeksaa viestinnän ammattilaista, joista kaikilla oli kokemusta vastuullisista viestintätehtävistä mainekriiseissä. Vaikka kokeneilta viestinnän ammattilaisilta saatiin kerättyä tutkimuskysymyksen kannalta riittävä ja rikas aineisto, 
saatuja tuloksia tulisi syventää ja tutkimuksen luotettavuutta parantaa keräämällä laajempi tutkimusaineisto ja kysymällä haastateltavilta suoraan nimenomaan kriisivuorovaikutuksen jännitteistä.

Kriisiviestinnän tutkimukset ovat usein olleet tapaustutkimuksia, ja muissa kuin tapaustutkimuksissa on taas tyypillisesti käytetty määrällisiä tutkimusmenetelmiä. Tapaustutkimusten tavoitteena on ollut erityisesti tietyn kriisin tapahtumien kuvailu, ja määrällisten tutkimusten tavoitteena on ollut etenkin kriisinhallintastrategioiden tehokkuuden arvioiminen. (An \& Cheng, 2012.) Vaikka tämän tutkimuksen aineisto ei ollut suuri, on tutkimuksen ansiona, että se laajentaa tapaustutkimusten näkökulmaa: tutkimuksessa tarkastellaan mainekriisien vuorovaikutusta rajoittumatta mihinkään tiettyyn mainekriisitapaukseen tai organisaatioon ja hyödynnetään samalla laadullisia tutkimusmenetelmiä. Näin onnistuttiin lisäämään ymmärrystä kriisivuorovaikutuksen jännitteistä mainekriiseissä yleisemmällä ilmiötasolla sekä jäsentämään viestinnän ammattilaisten työlle ominaista vuorovaikutusta ja merkityksenantoja.

Vuorovaikutus ei ole mainekriiseissä vain viestinnän ammattilaisten työtä. Jatkossa kriisivuorovaikutuksen jännitteitä olisi kiinnostavaa tarkastella myös organisaation johtajien, toimittajien ja muiden sidosryhmien näkökulmasta. Myös mahdolliset uravaiheeseen liittyvät sekä toimiala- ja organisaatiokohtaiset erot mainekriisien vuorovaikutuksessa ovat kiinnostava jatkotutkimuskohde. Kiinnostavaa olisi esimerkiksi selvittää, tarvitsevatko viestinnän ammattilaiset eri toimialoilla erilaista kriisivuorovaikutusosaamista.

Jatkossa olisi kiinnostavaa tarkastella myös, miten kriisivuorovaikutuksen jännitteisiin vastataan niin yksilöinä kuin kokonaisina organisaatioina; ratkaisevathan jännitteisiin vastaamistavat lopulta jännitteiden vaikutukset (Cools, 2011). Organisaatiot voivat tulkita kriiseissä saman jännitteen eri tavoin (Carlson ym., 2017). Kiinnostavaa ei olekaan vain, miten jännitteisiin vastataan, vaan myös se, miten niihin opitaan vastaamaan niin kuin niihin vastataan (Laajalahti, 2014).

Tutkimuksessa keskityttiin kriisivuorovaikutuksen jännitteisiin organisaation mainekriiseissä. Maineenhallinta edellyttää kuitenkin sidosryhmien tarpeiden ja toiveiden kuuntelua sekä vuorovaikutusta myös "hyvinä aikoina" ja sitä, että organisaatiot siirtyvät reaktiivisesta kriiseihin reagoinnista proaktiiviseen kriisien ennaltaehkäisyyn. Jatkossa olisikin kiinnostavaa tarkastella, millaisia vuorovaikutuksen jännitteitä organisaation maineenhallintaan liittyy "hyvinä aikoina".

Tutkimuksen perusteella organisaation maine on yhteydessä sidosryhmien keskuudessa ansaittuun luottamukseen. Tämän vuoksi tarkastelua tulisikin laajentaa myös vuorovaikutuksen jännitteisiin luottamuksen rakentamisen yhteydessä. Sosiaalinen media ei ole lisännyt vain mainekriisien uhkaa: organisaation luottojoukkoja (faith-holders) ovat sidosryhmät, jotka asettuvat vapaaehtoisesti puolustamaan organisaatiota kriisin syttyessä (Luoma-aho, 2015). Kriisejä ei siis tulisi tarkastella vain maineenhallinnan näkökulmasta vaan myös organisaation rakentamiin luottamussuhteisiin kohdistuvina uhkina. Menetetty luottamus vaikuttaa organisaation maineeseen, kun taas vahva luottamus turvaa mainekriisien pyörteissä. 


\section{Kirjallisuus}

An, S.-K., \& Cheng, I.-H. (2012). Crisis communication research in public relations journals: Tracking research trends over thirty years. Teoksessa W. T. Coombs, \& S. J. Holladay (toim.), The handbook of crisis communication (s. 65-90). West Sussex: Wiley-Blackwell. https://doi. org/10.1002/9781444314885.ch3

Avery, E. J., Lariscy, R. W., Kim, S., \& Hocke, T. (2010). A quantitative review of crisis communication research in public relations from 1991 to 2009. Public Relations Review, 36(2), 190-192. https://doi. org/10.1016/j.pubrev.2010.01.001

Baxter, L. A., \& Braithwaite, D. O. (2010). Relational dialectics theory, applied. Teoksessa S. W. Smith, \& S. R. Wilson (toim.), New directions in interpersonal communication research (s. 48-66). Los Angeles: Sage. http://dx.doi.org/10.4135/9781483349619.n3

Baxter, L. A., \& Montgomery, B. M. (1996). Relating: Dialogues and dialectics. New York: Guilford.

Baxter, L. A., \& Norwood, K. M. (2015). Relational dialectics theory: Navigating meaning from competing discourses. Teoksessa D. O. Braithwaite, \& P. Schrodt (toim.), Engaging theories in interpersonal communication: Multiple perspectives (2. painos, s. 279-291). Thousand Oaks: Sage.

Benoit, W. L. (2015). Accounts, excuses, and apologogies: Image repair theory and research (2. painos). New York: Suny Press.

Beurer-Züllig, B., Fieseler, C., \& Meckel, M. (2009). Typologies of communicators in Europe. Corporate Communications: An International Journal, 14(2), 158-175. https://doi. org/10.1108/13563280910953843

Carlson, E. J., Poole, M. S., Lambert, N. J., \& Lammers, J. C. (2017). A study of organizational responses to dilemmas in interorganizational emergency management. Communication Research, 44(2), 287-315. https://doi. org/10.1177/0093650215621775

Carroll, C. E. (2016). Introduction. Teoksessa C. E. Carroll (toim.), The SAGE encyclopedia of corporate reputation (xxv-xxix). Thousand Oaks: Sage. http:// dx.doi.org/10.4135/9781483376493

Cheng, Y. (2016). How social media is changing crisis communication strategies: Evidence from the updated literature. Journal of Contingencies and Crisis Management, 26(1), 58-68. https://doi. org/10.1111/1468-5973.12130
Cools, C. (2011). Relational dialectics in intercultural couples' relationships. Jyväskylän yliopisto. Jyväskylä Studies in Humanities 171.

Coombs, W. T. (2007). Ongoing crisis communication: Planning, managing, and responding (2. painos). Thousand Oaks: Sage.

Coombs, W. T. (2013). Situational theory of crisis: Situational crisis communication theory and corporate reputation. Teoksessa C. E. Carroll (toim.), The handbook of communication and corporate reputation (s. 262-278). West Sussex: John Wiley \& Sons. https://doi.org/10.1002/9781118335529.ch23

Currie-Mueller, J. L. (2017). Pointing fingers across the tracks: An examination of strategic messages in the Lac-Mégantic rail disaster. Journal of Risk Research, 21(10), 1197-1216. https://doi.org/10.108 $0 / 13669877.2017 .1281338$

Falkheimer, J., \& Heide, M. (2012). Crisis communication in change: From plans to improvisations. Teoksessa W. T. Coombs, \& S. J. Holladay (toim.), The handbook of crisis communication (s. 511-526). West Sussex: Wiley-Blackwell. https://doi. org/10.1002/9781444314885.ch25

Gerlander, M. (2003). Jännitteet lääkärin ja potilaan välisessä viestintäsuhteessa. Jyväskylän yliopisto. Jyväskylä Studies in Humanities 3.

Gerlander, M., Hautakangas, M., \& Ahva, L. (2018). Vuorovaikutuksen jännitteet toimittajan työssä: Sovittelujournalismin herättämiä näkökulmia. Teoksessa J. Koponen, L. Kokkonen, E. Kostiainen, \& I. A. Virtanen (toim.), Prologi: Puheviestinnän vuosikirja 2018 (s. 60-71). Jyväskylä: Prologos ry.

Gerlander, M., \& Kostiainen, E. (2005). Jännitteisyys opettajan ja oppijan vuorovaikutussuhteessa. Teoksessa T.-R. Välikoski, E. Kostiainen, E. Kyllönen, \& L. Mikkola (toim.), Prologi: Puheviestinnän vuosikirja 2005 (s. 68-87). Jyväskylä: Prologos ry.

Goodman, M. B. (2017). Communicating strategic change: The continuum of reputation, issues management, and crisis management is built on a positive corporate culture. Teoksessa L. Austin, \& Y. Jin (toim.), Social media and crisis communication (s. 41-56). New York: Routledge.

Hammarén, A. (2018). Viestinnän ammattilaisten kriisivuorovaikutus ja kriisivuorovaikutusosaaminen mainekriiseissä. Helsingin yliopisto, nykykielten laitos. Puheviestinnän pro gradu -tutkielma.

Hirsjärvi, S., \& Hurme, H. (2008). Tutkimushaastattelu: Teemahaastattelun teoria ja käytäntö. Helsinki: Gaudeamus. 
Kietzmann, J. H., Hermkens, K., McCarthy, I. P., \& Silvestre, B. S. (2011). Social media? Get serious! Understanding the functional building blocks of social media. Business Horizons, 54(3), 241-251. https://doi.org/10.1016/j.bushor.2011.01.005

Laajalahti, A. (2014). Vuorovaikutusosaaminen ja sen kehittyminen tutkijoiden työssä. Jyväskylän yliopisto. Jyväskylä Studies in Humanities 225.

Laajalahti, A. (2016). Kriisiviestinnästä kriisivuorovaikutukseen: Puheviestinnän näkökulmia kriiseissä ja kriiseistä viestimiseen. Teoksessa M. Siitonen, M. Lahti, J. Koponen, \& R. Vanhatalo (toim.), Prologi: Puheviestinnän vuosikirja 2016 (s. 76-82). Jyväskylä: Prologos ry.

Laajalahti, A., Hyvärinen, J., \& Vos, M. (2016). Crisis communication competence in co-producing safety with citizen groups. Social Sciences, 5(1), Art. 13. https://doi.org/10.3390/socsci5010013

Laaksonen, S. M. (2017). Hybrid narratives: Organizational reputation in the hybrid media system. Helsingin yliopisto. Publications of the Faculty of Social Sciences 53.

Littlefield, R. S. (2015). Introduction to the dialectical tensions of risk and crisis communication. Teoksessa R. S. Littlefield, \& T. L. Sellnow (toim.), Risk and crisis communication: Navigating the tensions between organizations and the public (s. 1-12). London: Lexington Books.

Littlefield, R. S., \& Sellnow, T. L. (toim.). (2015). Risk and crisis communication: Navigating the tensions between organizations and the public. London: Lexington Books.

Luoma-aho, V. (2015). Understanding stakeholder engagement: Faith-holders, hateholders \& fakeholders. Research Journal of the Institute for Public Relations, 2(1), 1-28.

McCorkindale, T., \& Distaso, M. W. (2013). The power of social media and its influence on corporate reputation. Teoksessa C. E. Carroll (toim.), The handbook of communication and corporate reputation (s. 497-512). West Sussex: John Wiley \& Sons. https://doi.org/10.1002/9781118335529.ch40

Ott, L., \& Theunissen, P. (2015). Reputations at risk: Engagement during social media crises. Public Relations Review, 41(1), 97-102. https://doi.org/10.1016/j.pubrev.2014.10.015

Putnam, L. L., Fairhurst, G. T., \& Banghart, S. (2016). Contradictions, dialectics, and paradoxes in organizations: A constitutive approach. The Academy of Management Annals, 10(1), 65-171. https://doi.org/ $10.1080 / 19416520.2016 .1162421$
Reynolds, B., \& Seeger, M. (2005). Crisis and emergency risk communication as an integrative model. Journal of Health Communication, 10(1), 43-55. https://doi.org/10.1080/10810730590904571

Sohn, Y. J., \& Lariscy, R. W. (2014). Understanding reputational crisis: Definition, properties, and consequences. Journal of Public Relations Research, 26(1), 23-43. https://doi.org/10.1080/1062726X.2013.795865

Tuomi, J., \& Sarajärvi, A. (2018). Laadullinen tutkimus ja sisällönanalyysi (uudistettu laitos). Helsinki: Tammi.

Ulmer, R. R., Sellnow, T. L., \& Seeger, M. W. (2015). Effective crisis communication: Moving from crisis to opportunity (3. painos). Thousand Oaks: Sage.

Viestinnän ammattilaiset (2017). Helsinki: ProCom ry, Viesti ry, Julkisen alan tiedottajat ry. https://www. viesti.fi/viestinta-ammattina/tutkimuksia-2 